\section{P. INTARAPALIT AND HIS POL NIKORN KIMNGUAN COMEDY}

\section{Vichitvong na Pombhejara ${ }^{1}$}

\begin{abstract}
The present paper briefly presents the life and works of Preecha Intarapalit with special reference to his immortal Pol Nikorn Kimnguan (PNK) comedy. Being acclaimed "the People's writer", P.Intarapalit's remarkable accomplishments as an author were not only for his voluminous work, but also for getting people into the habit of reading. However, the most valuable contribution of the PNK series was the recording of Thailand's social evolution over three decades in the form of an "oral history".
\end{abstract}

\section{P. Intarapalit and His Pon Nikorn Kimnguan Comedy}

Novels in Thai first appeared around the turn of the twentieth century when English-educated Thais found a literary pleasure in translating popular English novels into Thai with certain adaptations. These pioneering translated works were promptly accepted by Thai readers. Citing as examples often included Marie Corelli's "Vendetta" and Henry Rider Haggard's "She" and "King Solomon's Mines".

\footnotetext{
${ }^{1}$ Fellow

The Royal Institute ( Thailand )
}

A decade later, there appeared the first Thai novel by a Thai translator and author-"Khwam Mai Phayabat" (Benevolence) by "Nai Samran" (Luang Vila Parwat or "Khru Liam")

Since then Thai novels and other forms of fiction were written by Thai authors periodically. They reflected local background and current social values. In the late 1920's and the early 1930's when socio-economic changes were sweeping across the world, a new generation of Thai writers began to reflect their profound thoughts on complex problems that challenged the changing Thai society.

"Sri Burabha" (Kulap Sai Pradit), Momchao Akat Damkoeng, Dokmaisot" (Momluang Buppha Kunjara) were among social-concious authors at that time, whereas Manat Janyong, Sao Bunsanoe, San Thewarak, and Liao Srisewok were recognized as established novelists.

Early in 1933, a few months after the June 24 Revolution, a romantic novel, "Nakrian Nairoi" (Army Cadets), published by Phloenjit, a well-known publishing house, was a "bomb-shell" for the book market, incidentally introducing a young author by the name Preecha Intarapalit to the Thai literary world. The novel's first edition of more than 30,000 copies were instantly sold out.

The warm reception from readers led to other romantic novels by the same author who had captured the taste of the Thai public. P. Intarapalit sticked to this style of writing for 5 years and his novels were applauded the best sellers. 
However, by 1938 the public's taste for fiction began to change.

P.Intarapalit was persuaded by the publisher to switch from romance to comedy. Accepting the advice, he wrote the first episode of the comical series that were to become famous, "Aay Phuying" (Shyness), in early 1939. Once again the versatile writer found an instant success. His comedy was unique because it was imbued with romantic atmosphere typical of P.Intarapalit's novels.

In a few introductory episodes, the author brought out two main characters, Pol and Nikon, who were both cousins and buddies. Being the heirs to large fortunes of wealthy parents, the two handsome young men led a double life style. At home they were shy and reserved, but they became vivacious elsewhere, especially at entertainment places.

Soon afterward, the third character was brought in. Kimnguan was the only child of Thailand richest businessman. The three friends had many things in common apart from their wealth. They were fun-loving, joyous, active, and daring. Besides, they owned enough to afford lavish spendings.

The comical series of the three intimate friends, Pol, Nikorn, Kimnguan, unexpectedly magnetized the public's reading circle. Each "PKN" episode had a large circulation and it was brought out on a fortnightly interval. The PNK comedy became the best-known fiction in the literary history of Thailand.

For three decades, 1940's, 1950's, and
1960 's, more than 1,000 episodes of PNK of different lengths with a variety of plots and settings were written. In the meantime, P.Intarapalit found it necessary to create more characters; some of them to play leading roles in many episodes.

To mention just a few of them, "Chaokun Patchanuk", a retired general, fat, short, and bald, was the main object for humourous scenarios; "Doctor Direk", Chaokun Panjanuk's elder sonin-law, was an Oxford graduate in science and medicine. He was the principal character in PNK scientific episodes including the space adventures; "Ai Haow", Pol's valet, was given a supporting role in most episodes; "Lung Choei”, Pon's uncle from the countryside, was another character whose appearance in the series always creates a hilarious situation.

Between 1939-1941, P. Intarapalit wrote about 100 episodes which actually recorded current events before the outbreak of the Pacific War. There were about 3 millions of PNK copies in circulation during those years, being widely distributed throughout the country of 14 million people.

The Pacific War put a temporary brake on book publishings in Thailand, including the PNK series. The main reason was the shortage of newsprint and printing inks which had to be imported. The other reason, was due to the simplification of the Thai written language under the government's policy to eliminate illiteracy. Together with the Government's cultural reforms, which put emphasis on politeness in the use of language, many writers at that time 
decided to give up writing temporarily. After a few episodes on Thai-Japanese joint operations at the beginning of the war, P. Intarapalit wrote very little during 1942. But early in 1943, there appeared a relatively long episode which revealed the situation in Bangkok during the big flood in October and November 1942. The episode was written in the simplified language and strictly under the restricted cultural code at the time. "Por Saenkon" was perhaps the only PNK publication in that year and presumably not a very successful business undertaking.

In the second half of 1944 after the govermental measures on language simplification and cultural restriction had been lifted following a political change at the top, the Thai readers were happy to enjoy the PNK comedy in new episodes once again, although not so regularly, until the war ended in August 1945.

Since then until his untimely death in 1968, P. Intarapalit spent most of a quarter of the century producing around 1,000 new episodes in the PNK series. It is roughly estimated that since its first appearance in 1939, between 50-100 million copies of the PNK comedy have been published and read, an unsurpassed record for book printing in Thailand.

The renowned author has been anointed "people's writer" by a National Artist, Achin Panchapan.

Three decades after passing away, P.Intarapalit is still vivid in the public memory. His PNK comedy has continued to be widely read and incessantly talked about. The recent forming of a PNK club, "Samgler Connection (Three-buddies Connection)" on the internet with its own website and about 1,000 members both in Thailand and abroad evidently indicates that P. Intarapalit and his PNK series are by no means transitory. The new generation readers are not mainly looking for a laughter, but rather seeking a clear understanding of whatever written in the comedy such as places, customs, events, personalities etc., notwithstanding that it is just a fiction.

In other words, PNK readers at present tend to move towards "learning" from the series rather than "enjoying" them as originally intended by the author.

For older generation readers, there is a general agreement that the PNK series have induced them to get into the habit of reading, and in some cases, have imposed on them social values and a concept on life-style.

On the whole, the readers of all generations have agreed that the PNK series provide an "oral history" of the Thai society covering the period of three decades from 1939-1968. In more than 1,000 episodes are found the unintended recordings of events, personalities, social values,customs and traditions, political atmospheres, economic conditions, technological and scientific progress etc. Although most of the recorded accounts are casual, they are undoubtedly useful for learning social past on some details not to be found elsewhere.

The years between 1939-1941 saw Thailand emerged as a progressive nation under the new political regime 
which had been brought to power by the June 24, 1932 Revolution. It was the time the country was striving for a full sovereign state completely independent of foreign domination. Thailand was modern, nationalistic, and progressive. It was also the period when traditional values and customs were profoundly transformed into modernity.

Some of the best episodes in the PNK comedy were written during this period including the "Indochinese Conflict" which put the Thai military forces to test their strength and capabilities.

On December 8, 1941, The Pacific War encroached upon Thailand and for three and a half years, the country was under war-time conditions experiencing air raids and bombings, power blackouts, goods shortages, transportation cripples, school closedowns, evacuations, and the presence of foreign troops on the Thai soils. These war-time experiences were to some extent reflected in a few PNK episodes.

Returning to his usual task after the War, P.Intarapalit during 1945-1949 provided his PNK readers with a glimpse of the post-war scenario in Bangkok, while undertaking to produce the famous outlaws series, "Suea Bai" and "Suea Dam" on a daily basis. One of the early post-war episodes gave the scene of King Rama VIII's inspection of 17,000 British troops with Lord Mountbatten walking behind. The British troops were flown into Bangkok( to disarm the Japanese before sending them home) when the war ended.

During 1950-1954, the popular author wrote about Thailand's entering international conflicts. Upon the request of the United Nations, the Thai government sent combat troops to form parts of the UN forces which moved across the $38^{\text {th }}$ parallel to capture Pyongyang. At this time, Thailand decided to stand firmly on the United States' side and concluded many bilateral agreements with the Americans.

The next five years, 1955-1958, saw the communist threats increasingly perilous, while the internal political conflicts within the government went beyond a compromise. Although the PNK comedy always avoided politics, the readers were indirectly informed about the looming trouble at the horizon.

Nevertheless, the social life was by no means gloomy. The Thais still enjoyed life. The television age had arrived and there were two channels which placed an emphasis on entertainment value.

In the meanwhile, movies continued to be an important source of recreation for urban residents. Many new cinema halls were seen everywhere in Bangkok and other modern cities throughout the country. Apart from the imported films, mostly from Hollywood, Thai films were also popular among the movie-goers. Many PNK episodes were based on some movies that P. Intarapalit had enjoyed watching.

After the celebration of the $2,500^{\text {th }}$ Year of the Buddist Era in 1957, there was once again a political change that permanently ended the prolonged political career of Prime Minister P.Pibunsongkhram. A year later, the nation's fate fell upon Field Marshal Sarit Thanarat who was to rule Thailand 
for the next 5 years.

The new political leader took advice of the World Bank drawing an economic development plan to accelerate the country's socioeconomic progress. Nevertheless, under dictatorial government, many restrictions on human rights were imposed on the Thai society.

The PNK series casually furnished supplementary accounts on some phenomena during Sarit's regime, and extending the observations into the more relaxing period of Field Marshal Thanom Kittikhachorn during 19641968

In September 1968, P. Intarapalit completed his three-decade reports on Thailand's social changes. He never stopped writing until the last day of his life on the $25^{\text {th }}$ of that month, at age of 58.

A son of a colonel who was Head of the Thai language Department in the Army Academy, Preecha Intarapalit was entirely educated at that renowned institution, sharing classrooms with Sarit and Thanom, and other cadets who were to be prominent in the Thai army and Thai politics.

P. Intarapalit did not complete his military education, but left the academy to prepare himself for the career he loved, being a novelist. Once successful, he kept on writing to earn his living for 35 years as a professional and full-time writer. His writing was not for pleasure, but he aimed at giving pleasure to his readers. He succeeded.
Nevertheless, he was never aware that his continuous writings of the PNK series would in due time become an important evidence on "oral history" of three decades. In return, there were fame and money which were truly ample. He owned and drove cars while most middle-level government officials traveled by trams. He also owned a boxing training camp and managed a large diary farm. Unfortunately P. Intarapalit found no success in doing business.

His biography reveals that "the people's Writer" seemed to lead a happy life, with the exception of the last few years which he suffered a prolonged illness.

The problem was that his only source of income was writing. He, therefore, could not stop writing although his health was deteriorating. In any case, until the end of his life, P. Intarapalit never thought that it was his mistake to choose to achieve fame with a pen rather than a sword.

\section{References}

A book published on the writer's cremation. 1969.

"P. Intarapalit Memorial".

Reangchai Phutharo. 1985.

"P.Intarapalit: Cheevit Khong Konkhaifun",

Reangchai Phutharo. 1987. "P.Intarapalit: Nakprapun Mahasjan"

Prinya Intarapalit.1987. Lokesuantoua Khong P. Intarapalit". 
MANUSYA: Journal of Humanities 4.1, 2001

Vichitvong na Pombhejarạ. 1999. "Pol Nikorn, Kim-nguan".
Vichitvong na Pombhejara,.2001.

"Vivatanakarn Sangkomthai". 